\title{
Recombinant ferritin protein protects Penaeus monodon infected by pathogenic Vibrio harveyi
}

\author{
Biswajit Maiti, Rekha Khushiramani, Anuj Tyagi, Iddya Karunasagar, \\ Indrani Karunasagar*
}

Department of Fishery Microbiology, UNESCO Microbial Resource Centre (MIRCEN) for Marine Biotechnology, Karnataka Veterinary, Animal and Fisheries Sciences University, College of Fisheries, Mangalore 575002, India

\begin{abstract}
Hemocytes of shrimp perform an essential role in defense against microbial pathogens, involving both cellular and humoral factors. The gene coding for ferritin in black tiger shrimp Penaeus monodon was cloned, sequenced and expressed using pQE-30-UA vector and SG13009 Escherichia coli host cells. The deduced amino acid sequence of $P$. monodon ferritin showed 32 to $95 \%$ similarity with ferritin proteins of other organisms. The recombinant protein was purified by nickel-nitrilotriacetic acid affinity chromatography. A single thick band of recombinant protein of approximately $21 \mathrm{kDa}$ was observed in $15 \%$ sodium dodecyl sulfate polyacrylamide gel electrophoresis. Following mild acid treatment, 2 bands of ca. 14 and $7 \mathrm{kDa}$ were produced; aspartine and proline acid cleavage sites were found at amino acid residues 123-124. The purified recombinant ferritin helped in reducing the mortality in shrimp infected with Vibrio harveyi . However, no direct antimicrobial activity against pathogenic $V$. harveyi was observed.
\end{abstract}

KEY WORDS: Ferritin · Cloning and expression · Penaeus monodon · Vibrio harveyi $\cdot$ RT-PCR

\section{INTRODUCTION}

Crustaceans such as penaeid shrimp are often confronted with infectious microorganisms. Black tiger shrimp Penaeus monodon is the most economically important penaeid shrimp cultured in many parts of the world. Commercial farming of $P$. monodon has been worst hit by viruses such as white spot syndrome virus and bacteria such as Vibrio harveyi and $V$. alginolyticus considered to be secondary and opportunistic pathogens. To fight such infectious agents, phagocytic activity of several haemocyte types in circulation and humoral factors are important (Roch 1999). Crustacean haemocytes play an important role in the host immune response. They have mechanisms to detect microbial components, such as $\beta$-glucans, lipopolysaccharides (LPS), which can directly activate defensive cellular functions such as phagocytosis, melanization, encapsulation and coagulation. Innate immunity is contributed by inflammatory processes, generation of radical oxygen interme- diates, cytotoxic proteins and several families of antimicrobial peptides (Roch 1999).

Iron is an essential trace element in most living organisms and is regulated by specific transport and storage proteins, transferrin and ferritin, respectively (Park et al. 2005). Iron plays a central role in catalyzing reactive oxygen species production (superoxide radicals). Production of superoxide is an integral part of the crustacean immune system. Ferritin releases the stored iron molecules to a greater extent when blood iron is low, and to a lesser extent under high blood iron. A delicately balanced level of ferritin is required to maintain the iron level. Iron and oxygen chemistry under physiological conditions is corrosive, producing insoluble rust and soluble oxy radicals, and the expression of ferritin may differ according to environmental conditions such as pH stress (Zhou et al. 2008). Ferritin is widely distributed throughout the plant and animal kingdom in a highly conserved conformation. It helps in the storage of iron in a soluble, bioavailable and nontoxic form (Andrews et al. 1992). It also simultane- 
ously helps to arrange cellular defense against stress and inflammation (Torti \& Torti, 2002). Ferritin stores excess iron and plays an important role in cellular homeostasis as the physiological source of iron for the cell (Durand et al. 2004). Ferritin is a multimeric protein consisting of a 24 subunit protein shell comprising $21 \mathrm{kDa}$ heavy or $19 \mathrm{kDa}$ light chains. Each fragment has a specific function and can bind about 4500 iron atoms within the central cavity (Theil 1987, Harrison \& Arosio 1996). Ferritin molecules have been studied from microbial sources, including bacteria and fungi as well as higher plants and animals. Ferritin is responsible for resistance against oxidative stress in vertebrate systems and prevention of cell damage in both vertebrates and invertebrates (Orino et al. 2001). The increased level of ferritin also serves as a non-specific marker of inflammatory processes and neoplasms such as human breast cancer (Moroz et al. 1997) and renal cell carcinoma (Ozen et al. 1995). The protein plays a key role in the host defense response in animals and may be involved in the response against virus infection (Zhang et al. 20006). However, the potential role of ferritin gene in the defense of penaeid shrimp against bacterial infection remains unclear.

In the present study, ferritin gene from the tiger shrimp Penaeus monodon was cloned and expressed in Escherichia coli. The defense response of the recombinant P. monodon ferritin (rPmFer) protein was observed against pathogenic Vibrio harveyi. The nucleotide and deduced amino acid sequence of rPmFer was analyzed using bioinformatics based tools. Structural and functional studies of $P$. monodon ferritin will provide information on their role in defense response against $V$. harveyi in cultured shrimp.

\section{MATERIALS AND METHODS}

Shrimp. Healthy sub-adult Penaeus monodon weighing 15 to $20 \mathrm{~g}$ were used for the study. These individuals were collected from the southwest coast of India (Kundapur, Karnataka) and acclimatized in tanks of $500 \mathrm{l}$, containing seawater with $30 \mathrm{ppt}$ salinity, under continuous aeration for $2 \mathrm{wk}$.

Bacterial culture and experimental infection. A virulent strain of Vibrio harveyi, isolated from moribund larvae, was grown in tryptone soy (TS) broth with $2 \%$ $\mathrm{NaCl}$ and used to stimulate the expression of immunerelated genes, including ferritin. Overnight-grown bacterial cells were harvested by centrifugation (4000 $\mathrm{g}$ for $15 \mathrm{~min}$ ) and washed twice with sterile phosphate saline buffer (PBS). Total viable count was done using different dilutions $\left(10^{4}\right.$ to $\left.10^{7}\right)$ on TS agar plates. The culture was inactivated by heating at $60^{\circ} \mathrm{C}$ for $1 \mathrm{~h}$. An aliquot of $200 \mu \mathrm{l}$ bacterial suspension of $1.5 \times 10^{8}$ colony-forming units per milliliter ( $\mathrm{cfu} \mathrm{ml}^{-1}$ ) was injected intramuscularly between the $3 \mathrm{rd}$ and 4 th abdominal segments of the shrimp. Haemolymph was collected after $18 \mathrm{~h}$ with a syringe that had been rinsed and pre-loaded with $50 \mu \mathrm{l}$ of $2 \%$ EDTA solution. Haemocytes were separated by centrifuging at $5000 \mathrm{~g}$ for $10 \mathrm{~min}$. Unchallenged healthy sub-adult Penaeus monodon were used as a control for the experiment.

Reverse transcriptase (RT)-PCR and cloning. Total RNA from haemocytes was extracted using TRIzol reagent (Invitrogen), and the concentration was determined at the optical density (OD) ${ }_{260}$ using a UV-1601 spectrophotometer (Shimadzu). The RNA was reverse transcribed to cDNA from $2 \mu \mathrm{g}$ of RNA, using $2 \mu \mathrm{l}$ of oligo(dT) (100 $\left.\mathrm{ng} \mathrm{\mu l}^{-1}\right)$ and $0.5 \mu \mathrm{l}$ of RevertAid H minus (MBI Fermentas) at $42^{\circ} \mathrm{C}$ for $1 \mathrm{~h}$. A sequence of Pacific white shrimp Litopenaeus vannamei ferritin was retrieved from GenBank (Accession no. AY955373) and primers were designed from the flanking region of the gene. The sequences of primers were $\left(5^{\prime}-3^{\prime}\right)$ F-ATG GGG ATC CAA GTC CGC CAG and R-TTA GTG GAA TTC CTT ATC AAC. PCR was performed in a thermal cycler (MJ Research) in $30 \mu \mathrm{l}$ reaction volume containing 1.5 U Taq polymerase (Bangalore Genei), $3 \mu$ of $10 \times$ buffer $(500 \mathrm{mM} \mathrm{KCl}, 100 \mathrm{mM}$ Tris-HCl, $\mathrm{pH} 8.3,20 \mathrm{mM} \mathrm{MgCl}_{2}$ ), 50 to $100 \mathrm{ng}$ cDNA, $200 \mu \mathrm{M}$ of each of the 4 dNTPs and 10 pmol of each primer. Thirty-five cycles were carried out with denaturation at $95^{\circ} \mathrm{C}$ for $1 \mathrm{~min}$, annealing at $56^{\circ} \mathrm{C}$ for $1 \mathrm{~min}$ and extension at $72^{\circ} \mathrm{C}$ for $1 \mathrm{~min}$. The cycling included an initial delay at $95^{\circ} \mathrm{C}$ for $5 \mathrm{~min}$ and a final delay at $72^{\circ} \mathrm{C}$ for $10 \mathrm{~min}$. The PCR products were electrophoresed on $2 \%$ agarose gel. The product was purified using a PCR purification kit (Qiagen), ligated to commercial pQE30-UA linearized vector (Qiagen) at $16^{\circ} \mathrm{C}$ for $2 \mathrm{~h}$, and finally transformed into chemically competent SG13009 E. coli by heat shock. The recombinant transformants were selected using ampicillin $\left(100 \mu \mathrm{g} \mathrm{ml}^{-1}\right)$ and kanamycin $\left(25 \mu \mathrm{g} \mathrm{ml}^{-1}\right)$ on Luria Bertani (LB) agar plates, and further confirmed by PCR using gene specific primers (conditions already described).

DNA sequencing and analysis. The cloned product was sequenced by M/s Genei Bangalore, India. The nucleotide and derived amino acid sequences were analyzed using the BLAST program of NCBI (www. ncbi.nlm.nih.gov). The program Sequence QuickieCalc version 5.0 software was used for the prediction of molecular weight, isoelectric point (pI) and hydrophobic nature of the protein. The phylogenetic tree was constructed from CLUSTAL-generated alignment using the neighbor-joining method.

Expression and purification of ferritin. For testing the expression, overnight cultures of PCR-positive clones were inoculated into LB broth containing ampicillin $\left(100 \mu \mathrm{g} \mathrm{ml}^{-1}\right)$ and kanamycin $\left(25 \mathrm{\mu g} \mathrm{ml}^{-1}\right)$. Cul- 
ture showing 0.6 to $0.7 \mathrm{OD}_{600}$ was induced with $1 \mathrm{mM}$ of isopropyl $\beta$-D-1-thiogalactopyranoside (IPTG) for $4 \mathrm{~h}$. Whole cell lysates of the bacteria were prepared and the expression of the recombinant protein was studied in $15 \%$ sodium dodecyl sulfate polyacrylamide gel electrophoresis (SDS-PAGE) (Laemmli 1970). Uninduced recombinant clone and E. coli SG13009 host cells were used as a control. The protein was purified by nickel-nitrilotriacetic acid (Ni-NTA) affinity chromatography (Qiagen). The cell pellet was obtained after IPTG induction of recombinants, which lysed by applying lysis buffer (6 M GuHCl; $0.1 \mathrm{M}$ $\mathrm{NaH}_{2} \mathrm{PO}_{4} ; 0.01 \mathrm{M}$ TrisCl; $\mathrm{pH}$ 8.0). Cell debris was separated and clear lysate was mixed with $50 \% \mathrm{Ni}-\mathrm{NTA}$ slurry. This mixture was passed through from the column (Qiagen) and then washed with wash buffer (8 M urea; $0.1 \mathrm{M} \mathrm{NaH}_{2} \mathrm{PO}_{4} ; 0.01 \mathrm{M}$ TrisCl; $\mathrm{pH} 6.3$ and 5.9). Finally the recombinant protein was eluted using elution buffer (8 M urea; $0.1 \mathrm{M} \mathrm{NaH}_{2} \mathrm{PO}_{4} ; 0.01 \mathrm{M}$ TrisCl; $\mathrm{pH} 4.5)$. The purity of protein was examined by $15 \%$ SDS-PAGE and the concentration was estimated by Lowry's method (Lowry et al. 1951) using a UV-1601 spectrophotometer (Shimadzu).

Mild acid treatment. The cleavage activity of the recombinant ferritin protein was studied as described by Andrews et al. (1987) with minor modifications. The recombinant protein $\left(2.5 \mathrm{mg} \mathrm{ml}^{-1}\right)$ was dissolved in $70 \% \mathrm{v} / \mathrm{v}$ formic acid and $5 \mathrm{mM}-2$-mercaptoethanol. The sample was flashed with nitrogen $\left(\mathrm{N}_{2}\right)$ vapour, sealed and incubated at $37^{\circ} \mathrm{C}$ for $60 \mathrm{~h}$. The formic acid was evaporated under a stream of $\mathrm{N}_{2}$. The digested protein was freeze-dried and analyzed on $15 \%$ SDSPAGE.

Virulence assay. The virulence of Vibrio harveyi to Penaeus monodon was estimated and expressed as lethal dose $(\mathrm{LD})_{50}$ value (Reed \& Muench 1938). An $18 \mathrm{~h}$ bacterial culture in brain heart infusion (BHI) broth was harvested by centrifuge and washed with sterile PBS. Ten-fold serial dilutions of the culture pellet were made in PBS; $100 \mu \mathrm{l}$ of 4 consecutive dilutions $\left(1.5 \times 10^{4}, 1.5 \times 10^{5}, 1.5 \times 0^{6}\right.$ and $\left.1.5 \times 10^{7}\right)$ were injected intramuscularly to 10 shrimp each and mortality was observed up to $96 \mathrm{~h}$.

Effect on lethality of Vibrio harveyi for Penaeus monodon. From the virulence study it was estimated that $1.5 \times 10^{6} \mathrm{cfu} \mathrm{ml}^{-1}$ Vibrio harveyi culture was lethal for Penaeus monodon. Three groups of 30 shrimp each were used for the experiment. Each group consisted of 3 replicates of 10 individuals each. In the experimental setup, 1 group was injected with purified rPmFer protein $\left(1.5 \mathrm{\mu g} \mathrm{g}^{-1}\right.$ of shrimp), a second group with the mixture of rPmFer protein (1.5 $\mathrm{\mu g} \mathrm{g}^{-1}$ of shrimp) in $100 \mu \mathrm{l}$ of virulent $V$. harveyi culture at $1.5 \times 10^{6} \mathrm{cfu} \mathrm{ml}^{-1}$ and a third group with $100 \mu$ l of $V$. harveyi culture $\left(1.5 \times 10^{6} \mathrm{cfu} \mathrm{ml}^{-1}\right)$ alone. The shrimp were observed for mortality up to $96 \mathrm{~h}$. Protection was measured as relative percentage survival (RPS, Amend 1981). Any significant difference in the mortality between different groups was determined by 1-way ANOVA ( $\mathrm{p}<$ 0.05).

Study of antimicrobial activity against Vibrio harveyi. Direct antimicrobial activity of $\mathrm{rPmFer}$ against shrimp pathogenic $V$. harveyi was also studied by solid phase assay (Tyagi et al. 2007). For solid-phase assay, bacterial lawn was prepared on TS agar plates. After drying, $15 \mu \mathrm{g}$ of purified $\mathrm{rPmFer}$ protein was added to a $3 \mathrm{~mm}$ well, punched at the centre. Plates were incubated overnight at $30^{\circ} \mathrm{C}$. To study the effect of ferritin on viable count, $100 \mu$ l of overnight-grown $V$. harveyi was added to sufficient number of test tubes containing $4 \mathrm{ml}$ of LB broth and allowed to grow until an $\mathrm{OD}_{600}$ of 0.6 . After this, $60 \mu \mathrm{l}$ of recombinant ferritin $\left(1 \mu \mathrm{g} \mathrm{ll}^{-1}\right.$ in PBS) was added to these cultures in triplicate, resulting in final concentrations of $15 \mu \mathrm{g}$ ferritin $\mathrm{ml}^{-1}$ of culture. The mixtures were incubated at $30^{\circ} \mathrm{C}$ and viable counts by surface spreading were determined at $0 \mathrm{~min}$, $1 \mathrm{~h}$ and $2 \mathrm{~h}$. $V$. harveyi cultures containing $60 \mu \mathrm{l}$ of PBS were used as control.

\section{RESULTS}

\section{Cloning and expression of shrimp ferritin}

RNA from hemocytes of Penaeus monodon infected with Vibrio harveyi generated a 513 bp fragment gene coding for ferritin by RT-PCR. This purified product was cloned in pQE-30-UA expression vector. After antibiotic selection using ampicillin and kanamycin, positive clones were confirmed for the presence of insert by PCR. The recombinant protein was expressed after $4 \mathrm{~h}$ induction with $1 \mathrm{mM}$ IPTG. The expressed recombinant protein tagged with $6_{X}$-histidine had a slightly higher molecular weight of $21 \mathrm{kDa}$, as determined in $15 \%$ SDS-PAGE (Fig. 1), and a concentration of $7.5 \mathrm{mg} / 100 \mathrm{ml}$ of culture.

\section{Sequence analysis}

BLAST analysis of deduced amino acid sequence of rPmFer showed presence of conserved eukaryotic ferritin domain. The predicted protein was acidic with a pI of 5.2 and an estimated molecular weight of 19337.6 Da. Phylogenic comparison of deduced amino acid sequence of Penaeus monodon ferritin (Fig. 2) with that of light and heavy chains of ferritin of other organisms revealed conserved amino acids among the shrimp ferritin. Multiple protein sequence analysis showed its closeness to ferritin of Litopenaeus van- 
namei (95\%) and Fenneropenaeus chinensis (94\%). Distance relatedness was observed to Pacifastacus leniusculus ferritin (69\%), Artemia franciscana ferritin (58\%), Mus musculus ferritin (heavy chain) (58\%), Mus musculus ferritin (light chain) (58\%), Danio rerio ferritin (58\%), and an A-chain of recombinant Homo sapiens $\mathrm{H}$ ferritin (58\%).

Penaeus monodon ferritin showed least similarity with ferrin 1 subunit of Drosophila melanogaster (32\%,

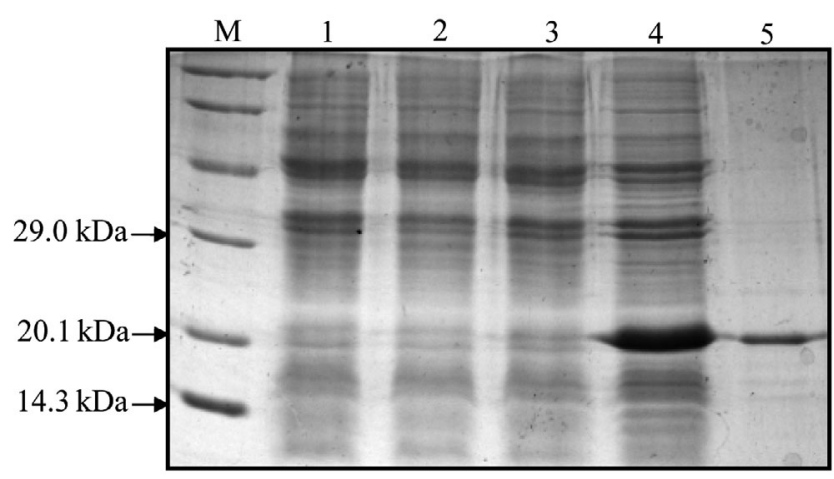

Fig. 1. M: PMW-M Protein Marker $\left(\mathrm{GeNei}^{\mathrm{TM}}\right)$. Lane 1: SG E. coli cells without isopropyl $\beta$-D-1-thiogalactopyranoside (IPTG) induction; Lane 2: SG E. coli cells with final $1 \mathrm{mM}$ IPTG induction; Lane 3: ferritin clone without IPTG induction; Lane 4: ferritin clone with final $1 \mathrm{mM}$ IPTG induction; Lane 5: purified ferritin protein

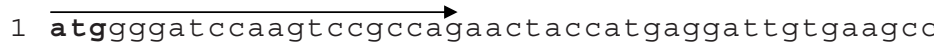

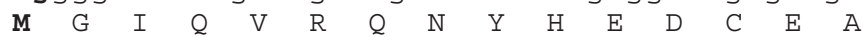

46 tccattaacaagcagatcaacatggaactttacgccagctacgtt $\begin{array}{lllllllllllllll}S & I & N & K & Q & I & N & M & E & L & Y & A & S & Y & V\end{array}$

91 taccttcgatggctcactacttcgaacgtgacgatgtagctctg $\begin{array}{llllllllllllllll}\mathrm{Y} & \mathrm{L} & \mathrm{S} & \mathrm{M} & \mathrm{A} & \mathrm{H} & \mathrm{Y} & \mathrm{F} & \mathrm{E} & \mathrm{R} & \mathrm{D} & \mathrm{D} & \mathrm{V} & \mathrm{A} & \mathrm{L}\end{array}$

136 cctggtttgccaagttcttcaaggatcgagcgatgaggaagg $\begin{array}{lllllllllllllll}P & G & F & A & K & F & F & K & E & S & S & D & E & E & R\end{array}$

181 gaacatgcccagattttcatgaagtaccagaacaagcgaggtggc

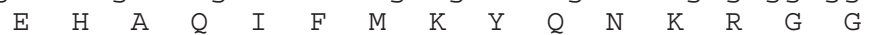

226 cgcatcgttctccagcagattgcagctcctccatgcaagatgg $\begin{array}{lllllllllllllll}R & I & V & L & Q & Q & I & A & A & P & S & M & Q & E & W\end{array}$

271 ggcactggtctggaagccettcaggctgctcttgatctggagaag $\begin{array}{lllllllllllllll}G & T & G & L & E & A & L & Q & A & A & L & D & L & E & K\end{array}$

316 caggtcatcagtctctcctggaactccatggcactgctagtggc $\begin{array}{lllllllllllllll}Q & V & N & Q & S & L & L & E & \text { L } & \text { H } & \text { G } & \text { T } & \text { A } & \text { S } & \text { G }\end{array}$

361 aacaatgatcc 4 catctcaccaagcttctgagatgagtatctg \begin{tabular}{llll|lllllllllll}
$\mathrm{N}$ & $\mathrm{N}$ & $\mathrm{D}$ & $\mathrm{P}$ & $\mathrm{H}$ & $\mathrm{L}$ & $\mathrm{T}$ & $\mathrm{K}$ & $\mathrm{L}$ & $\mathrm{L}$ & $\mathrm{E}$ & $\mathrm{D}$ & $\mathrm{E}$ & $\mathrm{Y}$ & $\mathrm{L}$
\end{tabular}

406 gaggaacaggtggattccatcaagaagattggtgacatgattacc

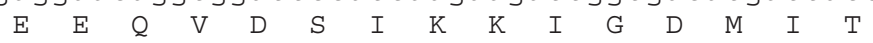

451 aagctgaagcgtgctggcccagctggtcttggagagtacttgtt

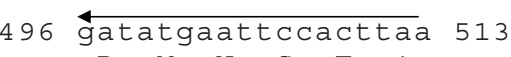

$\mathrm{D} \quad \mathrm{M} N \mathrm{~N} \quad \mathrm{~T}$ *

Fig. 2. Nucleotide and predicted amino acid sequence of the Penaeus monodon ferritin. Bold font and asterisk ( *) represents initiation and stop codon, respectively. Box shows aspartine (D) and proline (P) acid cleavage sites. Arrows indicates the primer binding portion, forward $(\rightarrow)$ and reverse primer $(\leftarrow)$

\section{Protection study}

Results of the experimental study of the protective nature of rPmFer are summarized in Fig. 5. Shrimp were protected when injected with the mixture of pathogenic Vibrio harveyi culture and the rPmFer protein, whereas $>90 \%$ mortality was observed when injected with $V$. harveyi alone. There was a statistically significant difference in survival between the V. harveyi control and $V$. harveyi with ferritin (ANOVA, p < 0.05). However, the rPmFer protein did not show any direct antimicrobial activity against $V$. harveyi by solid phase assays and there was no significant difference in viable $V$. harveyi counts between the control and ferritin containing cultures after $0 \mathrm{~min}, 1 \mathrm{~h}$ and $2 \mathrm{~h}$ incubation (Mann-Whitney $U$-test, $\mathrm{p}<0.05$, data not shown).

\section{DISCUSSION}

Ferritin is a member of the diiron-carboxylate protein superfamily and functions as an iron binding protein in a wide variety 


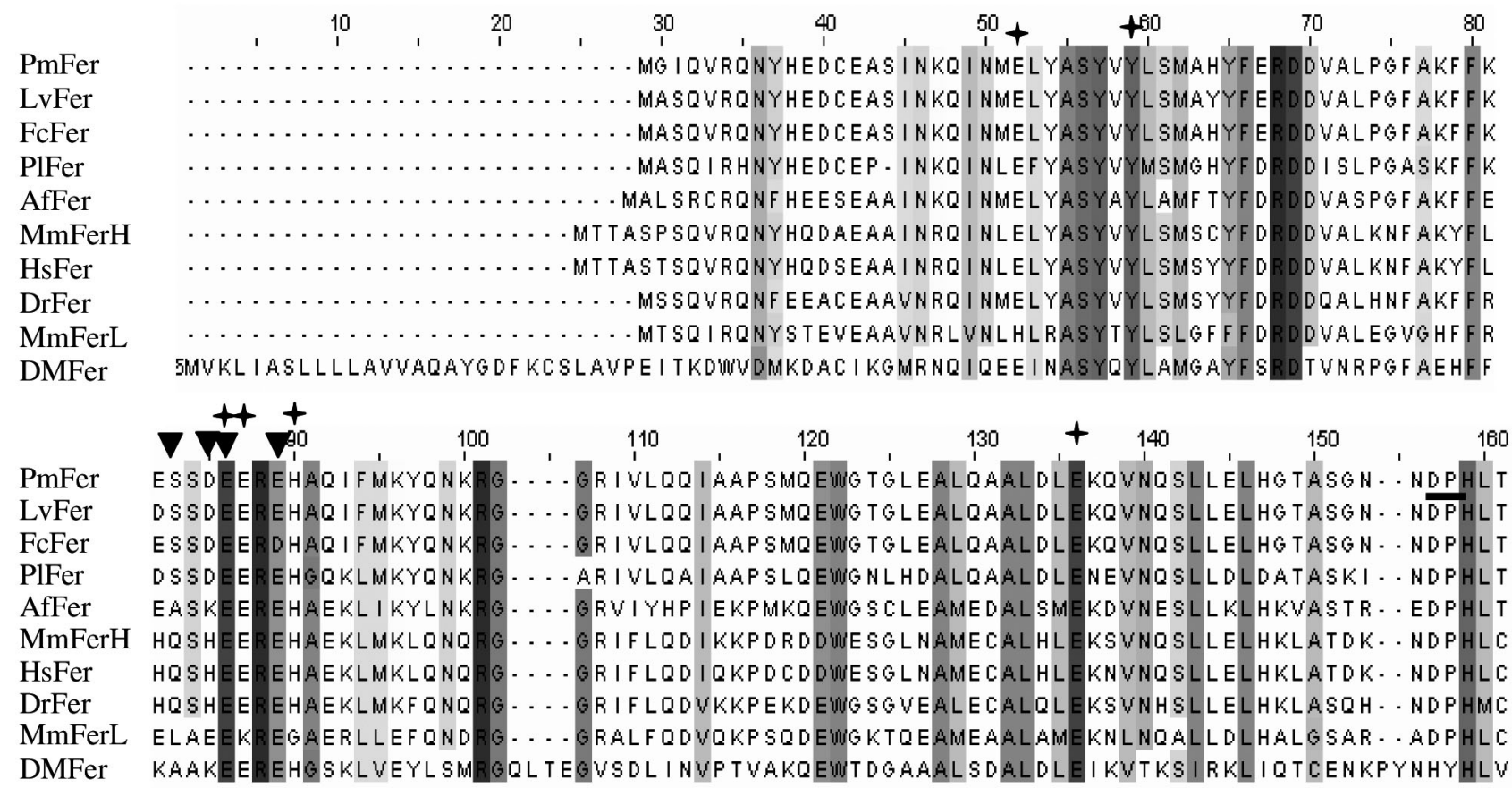

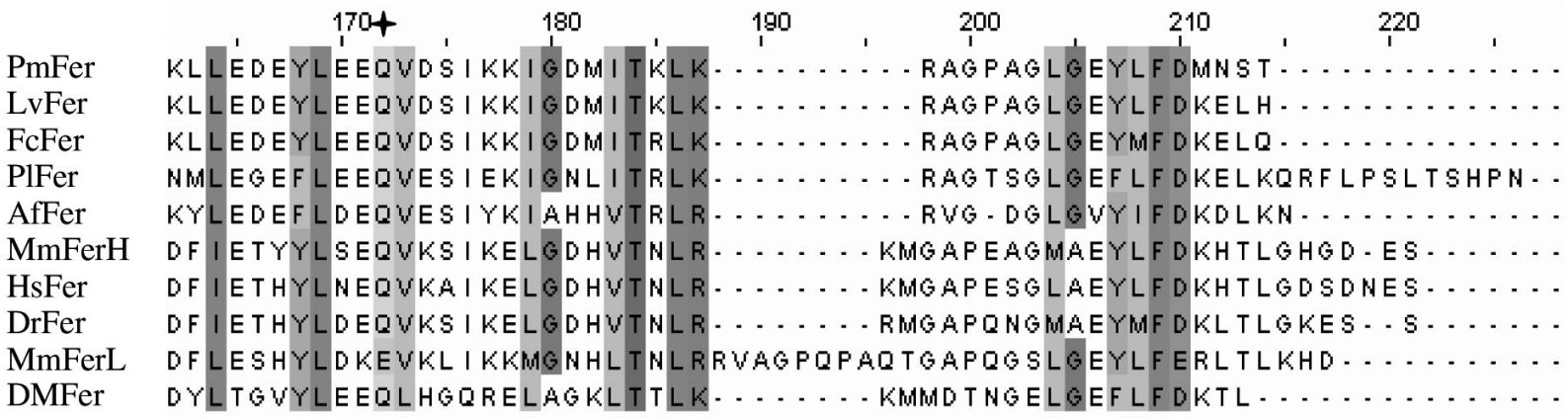

Fig. 3. Comparison of the amino acid sequences of ferritin. Similar intensity of grey shading shows the conserved amino acids. Symbols $(\boldsymbol{t})$ and $(\boldsymbol{\nabla})$ indicate the residues involved in formation of the ferroxidase center and ferrihydrite nucleation center, respectively. PmFer (Penaeus monodon, EF523241); LvFer (Litopenaeus vannamei, AAX55641); FcFer (Fenneropenaeus chinensi, ABB05537); PlFer (Pacifastacus leniusculus, CAA62186); AfFer (Artemia franciscana, AY062897); MmFerH (Mus musculus heavy chain, P09528); HsFer (Homo sapiens H ferritin A-chain, 2CEI_A), DrFer (Denio rerio, NP571660); MmFerlL (Mus musculus light chain, AAH83350); DmFer (Drosophila melanogaster, AAB70121). Underlined aspartine and proline (DP) residues for acid cleavage (Position 123-124)

of organisms (Andrews et al. 1992). In vertebrates, ferritin is a multimeric protein made up of 24 subunits of $\sim 20 \mathrm{kDa}$ consisting of heavy $(\mathrm{H})$ and light (L) chains in various ratios (Harrison \& Arosio 1996). Ferritin subunits $\mathrm{H}$ and $\mathrm{L}$ differ in rates of iron uptake and mineralization and have been characterized in some organisms. Fe (II) oxidation in the $\mathrm{H}$ subunits takes place initially at the ferroxidase center, which is a carboxylate-bridge diiron center located within the subunit four-helix bundle. H-ferritin may suppress proliferation of $\mathrm{T}$ cells (Matzner et al. 1979, 1985, Rosen et al. 1998), E-rosette formation (Wigginton 1995) and colony formation by human macrophages (Broxmeyer et al. 1986). In a complementary role, negatively charged residues on the inner surface of the L-subunit protein shell promote ferrihydrite nucleation. Although numerous studies on ferritin have been performed in vertebrates, mammals in particular, very little is known about the sequence and distribution of the transcripts in decapod crustaceans. Results from realtime quantitative RT-PCR (Hsieh et al. 2006) suggest that the ferritin expression is approximately 3 -fold more in haemocytes than the hepatopancreas. In the present study, the black tiger shrimp Penaeus monodon was challenged with inactivated bacteria to induce the non-specific immune response and haemo- 


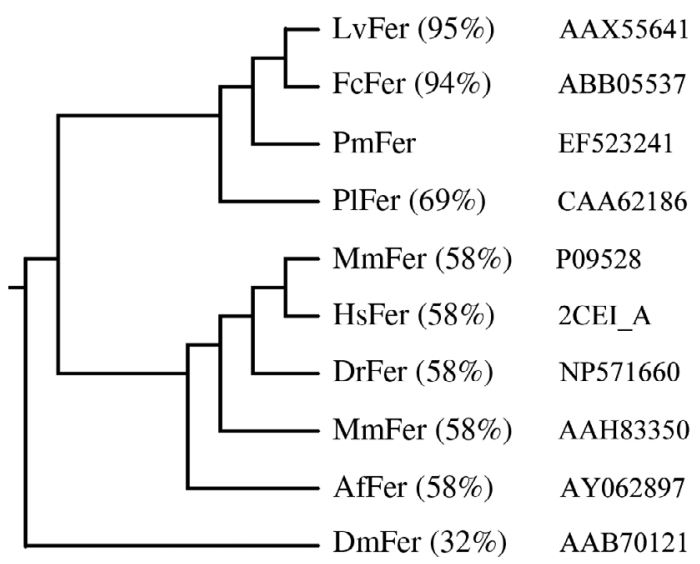

Fig. 4. Phylogenic comparison of ferritin. A phylogenetic tree was constructed as described in experimental procedures from the deduced amino-acid sequences of ferritin from several other organisms. The various accession numbers used are indicated in the tree. Percentage similarity of Penaeus monodon ferritin obtained in this study (PmFer) with other ferritin proteins has also been indicated. PmFer (Penaeus monodon, EF523241); LvFer (Litopenaeus vannamei, AAX55641); FcFer (Fenneropenaeus chinensi, ABB05537); PlFer (Pacifastacus leniusculus, CAA62186); AfFer (Artemia franciscana, AY062897); MmFerH (Mus musculus heavy chain, P09528); HsFer (Homo sapiens H ferritin A-chain, 2CEI_A), DrFer (Denio rerio, NP571660); MmFerlL (Mus musculus light chain, AAH83350); DmFer (Drosophila melanogaster, AAB70121)

cytes were collected for the RNA extraction. In the previous report on cDNA sequence of Fenneropenaeus chinensis (Zhang et al. 2006) and Litopenaeus vannamei (Hsieh et al. 2006), ferritin was cloned and sequenced. In $L$. vannamei, the preliminary full length cDNA sequence of $1249 \mathrm{bp}$ was obtained, including $132 \mathrm{bp}$ in the $5^{\prime}$ untranslated region, $510 \mathrm{bp}$ which encodes 170 amino acid residues and $607 \mathrm{bp}$ in the $3^{\prime}$ untranslated region (Hsieh et al. 2006).

In the present study, RT-PCR gave an amplicon of $513 \mathrm{bp}$ of coding region of ferritin from Penaeus monodon. The PCR amplified fragment was cloned in PQE30 -UA vector and sequenced. The sequence has been deposited in GenBank (Accession no. EF523241). This protein was expressed in SG13009 E. coli with $1 \mathrm{mM}$ IPTG induction. Purification was achieved by the guanidium hydrochloride denaturation method. Using the pQE-30-UA expression vector, the recombinant protein was obtained with N-terminal $6 \mathrm{X}$-histidine fusion proteins, with high yields through single-step purification. The expressed protein obtained was estimated to be approximately $21 \mathrm{kDa}$ by $15 \%$ SDS-PAGE; it has a slightly higher molecular weight than the native ferritin protein $(\sim 19 \mathrm{kDa})$ due to the presence of $6 \mathrm{x}$-histidine residues including some portions of the vector. The nature of the $\mathrm{rPmFer}$ protein was determined by treatment with mild acid. The sequence data

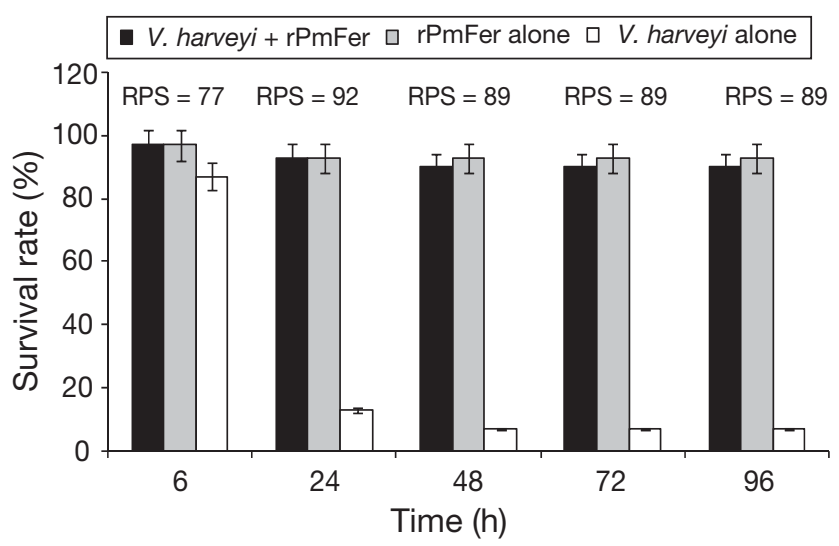

Fig. 5. Penaeus monodon. Error bar diagram (with $5 \%$ value) for relative percentage survival rate (RPS) of shrimp after injection with a mixture of rPmFer protein with Vibrio harveyi, purified rPmFer protein, or $V$. harveyi alone. Three groups of 30 shrimp (i.e. $n=30$ ) each were used. Significant difference in RPS obtained for different groups $(p<0.05)$. RPS $=$ [1 - (mortality of shrimp challenged with $V$. harveyi with rPmFer/mortality of $V$. harveyi alone)] $\times 100 \%$

obtained in the present study (Fig. 2) showed the presence of an Asp-Pro bond at amino acid residues (123-124) at the expected acid cleavage site (Piszkiewicz et al. 1970) which split the protein into 2 fragments of approximately 14 and $7 \mathrm{kDa}$. Two similar fragments were obtained when rat liver ferritin was treated with acid (Leibold et al. 1984). The P. monodon ferritin amino acid sequence deduced in the present study showed high similarity to the deduced ferritin amino acid sequences of other animals: $95 \%$ to $L$. vannamei, $94 \%$ to Fenneropenaeus chinensis, $69 \%$ to $P$. leniusculus, $58 \%$ to Artemia franciscana, $58 \%$ to both light and heavy chains of Mus musculus, $58 \%$ to Danio rerio, and $58 \%$ to the A-chain of human $\mathrm{H}$ ferritin. However, $P$. monodon ferritin showed little similarity (32\%) with Drosophila melanogaster ferritin (Fig. 3). During phylogenetic analysis, P. monodon ferritin formed a separate cluster with other shrimp ferritin proteins (Fig. 4) and showed a closer relationship with verterbrate ferritin than $D$. melanogaster ferritin. This indicates that Drosophila ferritin is unique to this organism and has evolved separately from other crustacean ferritins. The deduced amino acid sequence of P. monodon ferritin also had residues involved in the formation of the ferroxidase centre and ferrihydrite nucleation centre. Iron storage by a ferritin protein involves the uptake of Fe (II) at the protein shell, its oxidation by the molecular oxygen at dinuclear ferroxidase centre and movement of Fe (III) into the cavity for deposition as ferrihydrite. Thus, the presence of these ferroxidase and ferrihydrite nucleation centers in $P$. monodon ferritin indicates its oxidase and iron storage functions and possible role in iron detoxification and intracellular iron transport. 
The availability of iron has been shown to be a critical factor in the pathogenicity of microorganisms invading living hosts (Bullen 1981). Haemin, haemoglobin and all other iron sources found in homeothermic and/or poikilothermic hosts increase the lethal potential of pathogenic organisms such as Vibrio anguillarum (Nakai et al. 1987), V. damsela (Fouz et al. 1994) and V. vulnificus (Stelma et al. 1992, Magarinos et al. 1994). In the present study, when shrimps were injected with virulent $V$. harveyi and ferritin, there was a high level of protection offered, possibly due to a reduction in the lethality of the organism (Fig. 5). There was no mortality observed when ferritin alone was injected to shrimp. $V$. harveyi alone resulted in $>90 \%$ mortality. However, recombinant ferritin did not show any direct antimicrobial activity against $V$. harveyi, and its addition did not reduce viable counts of $V$. harveyi. These results suggest that the PmFer protein may be involved in the defense response against $V$. harveyi, possibly by restricting the availability of iron, which is required for the organism to survive and multiply inside the host body.

Acknowledgements. Financial support from the Department of Biotechnology, Government of India, through the project 'Functional genomics of the shrimp Penaeus monodon' is gratefully acknowledged.

\section{LITERATURE CITED}

Amend DF (1981) Potency testing of fish vaccines. Dev Biol Stand 49:447-454

> Andrews SC, Treffry A, Harrison PM (1987) A new form of ferritin heterogeneity explained: isolation and identification of a nineteen-amino-acid-residue fragment from sideosomal ferritin of rat liver. Biochem J 245:447-453

Andrews SC, Arosio P, Bottke W, Briat JF and others (1992) Structure, function, and evolution of ferritins. J Inorg Biochem 47:161-174

Broxmeyer HE, Lu L, Bicknell DC, Williams DE and others (1986) The influence of purified recombinant human heavy-subunit and light-subunit ferritins on colony formation in vitro by granulocyte-macrophage and erythroid progenitor cells. Blood 68:1257-1263

Bullen JJ (1981) The significance of iron in infection. Rev Infect Dis 3:1127-1138

> Durand JP, Goudard F, Pieri J, Escoubas JM, Schreiber N, Cadoret JP (2004) Crassostrea gigas ferritin: cDNA sequence analysis for two heavy chain type subunits and protein purification. Gene 338:187-195

Fouz B, Toranzo AE, Biosca EG, Mazoy R, Amaro C (1994) Role of iron in the pathogenicity of Vibrio damsela for fish and mammals. FEMS Microbiol Lett 121:181-188

> Harrison PM, Arosio P (1996) The ferritin: molecular properties, iron storage function and cellular regulation. Biochim Biophys Acta 1275:161-203

Hsieh SL, Chiu YC, Kuo CM (2006) Molecular cloning and tissue distribution of ferritin in Pacific white shrimp (Litopenaeus vannamei). Fish Shellfish Immunol 21:279-283

Laemmli UK (1970) Cleavage of structural proteins during the assembly of the head of bacteriophage T4. Nature 227:680-685

Leibold EA, Aziz N, Brown AJ, Munro HN (1984) Conserva- tion in rat liver of light and heavy subunit sequences of mammalian ferritin. Presence of unique octopeptide in the light subunit. J Biol Chem 259:4327-4334

> Lowry OH, Rosebrough NJ, Farr AL, Randall RJ (1951) Protein measurement with the folin phenol reagent. J Biol Chem 193:265-275

Magarinos B, Romalde JL, Lemos ML, Barja JL, Toranzo AE (1994) Iron uptake by Pasteurella piscicida and its role in pathogenicity for fish. Appl Environ Microbiol 60: 2990-2998

Matzner Y, Hershko C, Polliack A, Konjin AM, Izak G (1979) Suppressive effect of ferritin on in vitro lymphocyte function. Br J Haematol 42:345-353

Matzner Y, Konjin AM, Shlomai Z, Ben-Bassat H (1985) Differential effect of isolated placental isoferritins on in vitro T-lymphocyte function. Br J Haematol 59:443-448

> Moroz C, Chetrit A, Kahn M, Modan B (1997) FBL blood test as a predictive marker of breast cancer in high risk women. Med Oncol 14:39-42

Nakai TT, Kanno ER, Cruz Muroga K (1987) The effects of iron compounds on the virulence of Vibrio anguillarum in Japanese eels and ayu. Fish Pathol 22:185-189

Orino K, Lehman L, Tsuji Y, Ayski H, Torti SV, Torti FM (2001) Ferritin and the response to oxidative stress. Biochem J 357:241-247

> Ozen H, Uygur C, Sahin A, Tekgul S, Ergen A, Remzi D (1995) Clinical significance of serum ferritin in patients with renal cell carcinoma. Urology 46:494-498

Park RY, Sun HY, Choi MH, Bai YH, Shin SH (2005) Staphylococcus aureus siderophore-mediated iron-acquisition system plays a dominant and essential role in the utilization of transferrin-bound iron. J Microbiol 43:183-190

> Piszkiewicz D, Landon M, Smith EL (1970) Anomalous cleavage of aspartyl-proline peptide bonds during amino acid sequence determinations. Biochem Biophys Res Commun 40:1173-1178

Reed LJ, Muench H (1938) A simple method of estimating fifty percent end points. Am J Epidemiol 27:493-497

Roch P (1999) Defense mechanisms and disease prevention in farmed marine invertebrates. Aquaculture 172:125-145

Rosen HR, Ausch C, Reinerova M, Zaspin E and others (1998) Activated lymphocytes from breast cancer patients express the characteristic of type 2 helper cells - a possible role for breast cancer-associated p43. Cancer Lett 127: 129-134

Stelma GN, Reyes AL, Peeler JT, Johnson CH, Spaulding PL (1992) Virulence characteristics of clinical and environmental isolates of Vibrio vulnificus. Appl Environ Microbiol 58:2776-2782

> Theil EC (1987) Ferritin: structure, gene, regulation and cellular function in animals, plant and microorganisms. Annu Rev Biochem 56:289-315

Torti FM, Torti SV (2002) Regulation of ferritin genes and proteins. Blood 99:3505-3516

- Tyagi A, Khushiramani R, Karunasagar I, Karunasagar I (2007) Antivibrio activity of recombinant lysozyme expressed from black tiger shrimp, Penaeus monodon. Aquaculture 272:246-253

- Wigginton JM (1995) Reversal of ferritin-mediated immunosupression by levamisole: a rationale for its application to management of the acquired immune deficiency syndrome (AIDS). Med Hypotheses 44:85-88

> Zhang J, Li F, Wang Z, Zhang X, Zhou Q, Xiang J (2006) Cloning, expression and identification of ferritin from Chinese shrimp, Fenneropenaeus chinensis. J Biotechnol 125:173-184

Zhou J, Wang WN, Ma GZ, Wang AL and others (2008) Gene expression of ferritin in tissue of the Pacific white shrimp, Litopenaeus vannamei after exposure to $\mathrm{pH}$ stress. Aquaculture 275:356-360 